\title{
Anti-migration and Anti-invasion Abilities of Methanolic Leaves Extract of Clerodendrum Inerme on Lung Cancer Cells
}

\author{
Malatee Tayeh ${ }^{1, *}$, Poonsit Hiransai ${ }^{1}$, Hathaichanok Kommen ${ }^{2}$, Ramida Watanapokasin ${ }^{3}$
}

\author{
Malatee Tayeh ${ }^{1, *}$, Poonsit \\ Hiransai', Hathaichanok \\ Kommen ${ }^{2}$, Ramida \\ Watanapokasin ${ }^{3}$
}

'School of Allied Health Sciences, Walailak University, Nakhon Si Thammarat 80160 , THAILAND.

${ }^{2} S$ chool of Sciences, Walailak University, Nakhon Si Thammarat 80160, THAILAND. ${ }^{3}$ Department of Biochemistry, Faculty of Medicine, Srinkharinwirot University, Bangkok 10110, THAILAND.

\section{Correspondence}

\section{Malatee Tayeh}

School of Allied Health Sciences, Walailak University, Nakhon Si Thammarat, THAILAND.

Phone no.: +66-75-672602;

E-mail: malateetayeh@gmail.com,

tmalatee@wu.ac.th

History

- Submission Date: 03-05-2020;

- Review completed: 21-05-2020;

- Accepted Date: 12-06-2020.

DOI : 10.5530/pj.2020.12.145

Article Available online

http://www.phcogj.com/v12/i5

\section{Copyright}

(C) 2020 Phcogi.Com. This is an openaccess article distributed under the terms of the Creative Commons Attribution 4.0 International license.

\begin{abstract}
Background: Clerodendrum inerme is a folk medicinal plant used in the treatment of various illnesses such as a cough, scrofulous infection, venereal infection, skin diseases and tumors. It exhibited many pharmacological effects including hepatoprotective, anti-inflammatory, antibacterial, anti-oxidant and anticancer properties. Objective: The purpose of this study was to investigate the influence of methanolic extract of $C$. inerme leaves on migration, invasion and adhesion activities on human lung adenocarcinoma. Materials and methods: Cytotoxicity, cell motility, migration, invasion and adhesion abilities were detected by MTT, wound healing, trans-well mobilization, modified Boyden chamber and cell adhesion assay, respectively. Results: The results demonstrated that up to $400 \mu \mathrm{g} / \mathrm{mL}$ methanolic leaves extract has low toxicity on A549 cells showing more than $50 \%$ cell viability. At non-cytotoxic and sub-toxic doses (200 and $400 \mu \mathrm{g} / \mathrm{mL}$ ) of methanolic leave extract significantly suppressed cell motility, migration, invasion and cell adhesion compared with the untreated control. Conclusion: These results suggested that methanolic leaves extract of $C$. inerme inhibited migration, invasion and adhesion of A549 cells. These findings showed new therapeutic potential for $C$. inerme in anti-metastatic therapy.
\end{abstract}

Key words: Clerodendrum inerme, Anti-migration, Anti-invasion, Human lung adenocarcinoma.

\section{INTRODUCTION}

Lung cancer is the most common cancer types in men and fourth cancer in women. It is the major cause of cancer-related death in the world. There are about 1,350,000 newly developed cases and $1,180,000$ death cases of lung cancer, globally. Lung cancer is divided into two major types, small cell lung cancer (SCLC) and non-small cell lung cancer (NSCLC). ${ }^{1}$ Non-small cell lung cancer (NSCLC) is the most common type that accounts for $80-90 \%$ of lung cancers, which is divided into 3 major pathologic subtypes including adenocarcinoma, squamous cell carcinoma and large cell carcinoma. ${ }^{2}$ About $30-40 \%$ of patients with advanced NSCLC will develop metastasis, which is the lung cancer cells migrate to and invade to the distant organs, such as bones, brain and contralateral lung. ${ }^{3}$ Metastasized lung cancer is difficult for treatment because it is highly resistant to radiation and conventional chemotherapeutic agents. It is the main cause of cancer-related death in lung cancer patients. ${ }^{4,5}$ Thus, the potential therapeutic agent for treating lung cancer metastasis is an urgent therapeutic need.

Clerodendrum inerme is a medicinal plant in the family Verbenaceae. Its common names include glory bower, bag flower, and bleeding-heart. ${ }^{6}$ It is widely distributed in South and South-east Asia, Australia and Pacific islands. ${ }^{7}$ Different parts of C. inerme are used as a traditional medicine for the treatment of rheumatism, cough, scrofulous infection, venereal infection, skin diseases, beriberi, and tumors. ${ }^{8-10}$ The leaves of $C$. inerme are used for treating fever, cough, skin rashes, chronic pyrexia and boils, and are used in conjunction with other plant leaves. ${ }^{11} \mathrm{C}$. inerme exhibited many pharmacological effects including hepatoprotective, ${ }^{12}$ antiinflammatory, ${ }^{13}$ anti-bacterial, ${ }^{14-16}$ anti-oxidant, ${ }^{17}$ antidiabetic, ${ }^{18}$ antiparasitic, ${ }^{19}$ antiallergic, ${ }^{20}$ and anticancer ${ }^{21-24}$ activities. Recent studies showed that C. inerme leaves extract displays antiproliferation and anticancer activities on lung cancer cell line A549..$^{25,26}$ However, the anti-migration, anti-invasion and anti-adhesion activities of $C$. inerme leaves extract on cancer cells have not been reported. Therefore, the present study investigated the inhibitory effect of methanolic leaves extract of $C$. inerme on cancer migration, invasion and adhesion in A549 cells.

\section{MATERIALS AND METHODS}

\section{Chemical reagents}

Dimethylsulfoxide (DMSO), trypan blue and 3-(4,5-Dimethylthiazol-2-yl)-2,5-diphenyl-2Htetrazolium bromide (MTT) were purchased from Sigma-Aldrich (St. Louis, MO, U.S.A). Phosphate buffered saline was purchased from Merck Millipore Corp (Darmstadt, Germany). Powdered Dulbecco's modified Eagle's medium (DMEM) was purchased from Gibco/BRL (Gaithersburg, MD, U.S.A). Matrigel matrix was purchased from Corning incorporated (Bedford, MA, U.S.A).

Collection of plant material and extract preparation

C. inerme leaves were collected from Pak-Poon Community, Muang District, Nakhon Si Thammarat

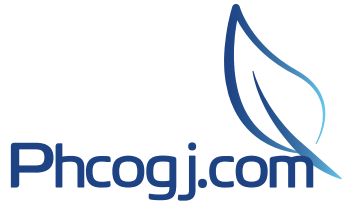

Cite this article: Tayeh $\mathrm{M}$, Hiransai $\mathrm{P}$, Kommen $\mathrm{H}$, Watanapokasin R. Anti-migration and Antiinvasion Abilities of Methanolic Leaves Extract of Clerodendrum Inerme on Lung Cancer Cells. Pharmacogn J. 2020;12(5):1024-31. 
Province. Fresh leaves were washed under running tap water and then dried for 36 hours using a hot air oven at $60^{\circ} \mathrm{C}$. Dried leaves were crushed and subjected to extraction using the maceration process in methanol for 7 days at temperature. The extracts were collected and concentrated at $40^{\circ} \mathrm{C}$ under reduced pressure using a rotary evaporator. The dried extracts were stored at $4^{\circ} \mathrm{C}$ until further use.

\section{Cell culture}

The human non-small cell lung cancer (NSCLC) cell lines, A549 was obtained from the American Type Culture Collection (Rockville, MD). A549 cells were cultured in DMEM supplemented with 10\% FBS (Life Science, Little Chalfont, UK), $100 \mathrm{U} / \mathrm{mL}$ penicillin and $100 \mu \mathrm{g} / \mathrm{mL}$ streptomycin (Life Science, Little Chalfont, UK) at $37^{\circ} \mathrm{C}$ in a humidified atmosphere of $5 \% \mathrm{CO}_{2}$.

\section{Cell viability assays}

An MTT assay was carried out to determine the cytotoxic effect of methanolic extract of $C$. inerme leaves on A549 cells. The cells were plated in 96-well plate at a density of $7 \times 10^{3}$ cells/well and treated with methanolic extract at different concentrations $(0,6.25,12.5,25,50,100$, 200 , and $400 \mu \mathrm{g} / \mathrm{mL}$ ) for 24 hours. After incubation, $0.5 \mathrm{mg} / \mathrm{mL}$ of MTT solution was added to each well and the plates were further incubated for 2 hours at $37^{\circ} \mathrm{C}$. The supernatant was removed, and $100 \mu \mathrm{L}$ of DMSO was added to solubilize the water-insoluble purple formazan crystals. The absorbance was measured using a Microplate spectrophotometer at $570 \mathrm{~nm}$ and cell viability percentage (\%) was calculated relative to the control. $\mathrm{IC}_{50}$ (inhibitory concentration 50\%) value was calculated using the software GraphPad Prism 3.03 (GraphPad Software Inc., San Deigo, CA). Cell viability assay was performed with three independent experiments.

\section{Wound healing assay}

Wound-healing assay was performed to determine cell motility of A549. Briefly, the cells were seeded a density of $30 \times 10^{4}$ cells $/ \mathrm{mL}$ in 6-well plates until $90 \%$ confluence. Then the cells were scratched with a sterile $200 \mu \mathrm{L}$ pipette tip to generate the wound area. Cellular debris was washed with phosphate buffer saline, and cells were treated with non-toxic concentrations of methanolic extract $(0,200$ and $400 \mu \mathrm{g} / \mathrm{mL})$ for 24 hours. The wound closure was observed and photographed at 24 hours with an inverted microscope. The wound area was measured by NIH ImageJ software (NIH, Bethesda, MD). The experiments were repeated three times.

\section{In vitro migration assay}

Effect of methanolic extract of $C$. inerme leaves on cell migration was assayed by 24 well transwell chambers. Cells were seeded in $35 \mathrm{~mm}^{3}$ dishes and treated with 0,200 and $400 \mu \mathrm{g} / \mathrm{mL}$ for 24 hours. After incubation time, cells were harvested and seeded to the upper chamber of the transwell insert (polyethylene terephthalate (PET) filters with $8 \mu \mathrm{M}$ pore size, corning life sciences) in serum-free medium. FBS medium as a chemoattractant was added to the lower chamber, and thereafter these transwell inserts were incubated for 24 hours at $37^{\circ} \mathrm{C}$ in $5 \%(\mathrm{v} / \mathrm{v}) \mathrm{CO}_{2}$. After incubation, the non-migratory cells were removed with a cotton swab and those on the lower surface of the membrane were fixed with methanol and stained with $0.5 \%$ crystal violet. Cells that migrate through the membrane were viewed and photographed under an inverted microscope. The percentage of the migratory cells for each treatment was calculated by NIH ImageJ software (NIH, Bethesda, $\mathrm{MD})$.

\section{Cell invasion assay}

Effect of methanolic extract of C. inerme leaves on cancer cells to invade through membrane coated with $30 \mu \mathrm{g}$ of Matrigel (Corning incorporated, Bedford, MA, USA) was measured by Modified Boyden chamber assay. ${ }^{27}$ A549 cells were pretreated with 0,200 and $400 \mu \mathrm{g} / \mathrm{mL}$ of the extracts for 24 hours. Cells in serum-free medium were seeded onto the upper chamber and medium containing 10\% FBS was added into the lower chamber as a chemoattractant. The Boyden chamber was incubated for 24 hours at $37^{\circ} \mathrm{C}$. At the end of incubation, the cells in the upper surface of the membrane were removed with a cotton swab. Cells that invade across the Matrigel to the lower surface of the membrane were fixed with methanol, stained with $0.5 \%$ crystal violet and washed with PBS. The invading cells on the lower surface of the membrane filter were viewed and photographed under an inverted microscope. The data are presented as the percentage of cell invasion from five random fields.

\section{Cell adhesion assay}

Effect of methanolic extract of $C$. inerme leaves on adhesion ability of A549 cells was determined by 3-(4,5-dimethyl 2-thiazolyl)-2,5diphenyltetrazolium bromide (MTT) assay. ${ }^{28,29}$ Cells were pretreated with different concentrations of the extracts $(0,200$ and $400 \mu \mathrm{g} / \mathrm{mL})$ for 24 hours, then $1 \times 10^{4}$ cells/well were seeded into the Matrigel-coated 96well plate for 1 hour. After incubation time, the non-adherent cells were removed with $\mathrm{PBS}$. The adherent cells were reacted with $0.5 \mathrm{mg} / \mathrm{mL}$ of MTT solution at $37^{\circ} \mathrm{C}$ for 2 hours. After that $100 \mu \mathrm{L}$ of DMSO was added to each well to solubilize the water-insoluble purple formazan crystals. The absorbance was measured at $570 \mathrm{~nm}$ using a microplate reader. The percentage (\%) of cell adhesion was calculated relative to the control.

\section{Statistical analysis}

All data were edited and entered for the statistical analyses using the SPSS 17.0 software package. Data were reported as mean \pm standard deviation $( \pm S D)$ of three independent experiments. Statistical significance was analyzed by the one-way ANOVA test. The differences between treatment groups and the untreated group were considered statistically significant at $p<0.05$.

\section{RESULTS}

\section{Cytotoxic effect of methanolic leaves extract on C. inerme on A549 cells}

The cytotoxicity of methanolic leaves extract of C. inerme on A549 cells was determined by MTT assay and the results are shown in Figure 1. There was no significant effect on cell viability after treatment with methanolic leaves extract of C.inerme $(6.25-200 \mu \mathrm{g} / \mathrm{mL})$ but the high concentration, the extract significantly inhibited cell growth of A549 cells. The $20 \%$ inhibitory concentration $\left(\mathrm{IC}_{20}\right)$ and $50 \%$ inhibitory concentration $\left(\mathrm{IC}_{50}\right)$ of the extracts were greater than $400 \mu \mathrm{g} / \mathrm{mL}$. The non-cytotoxic and sub-cytotoxic concentrations (200 and $400 \mu \mathrm{g} / \mathrm{mL}$ showing $>80 \%$ cell viability) of methanolic leaves extract of $C$. inerme were used for subsequent experiments.

\section{The effect of methanolic leaves extract on C. inerme on cell migration}

The anti-migration effects of the methanolic leaves extract of $C$. inerme were determined by using wound healing and transwell chamber assay. The cell monolayers were scratched with a micropipette tip to create the wound area. After treatment with non-toxic concentrations of $C$. inerme leaves extract for 24 hours, cells migrated to the wound area and the wound closure was analyzed. The result showed that the methanolic leaves extract of $C$. inerme could reduce migration of A549 cells to the wound area in a dose-dependent manner when compared with the untreated cells (Figure 2A and 2B). Treatment with methanolic 


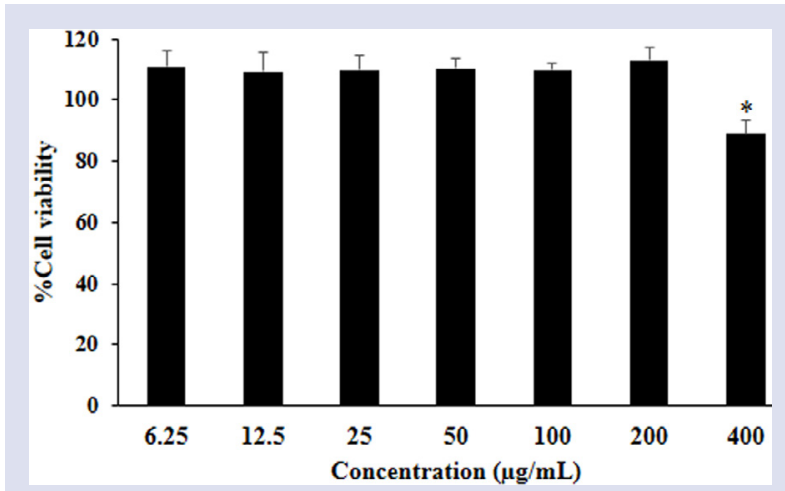

Figure 1: Cytotoxicity of methanolic leaves extract of $C$. inerme on $\mathrm{A} 549$ cell lines. A549 cells were treated with methanol leaves extract of $C$. inerme at different concentrations for 24 hours. The non-cytotoxic and sub-cytotoxic concentrations (lower than $400 \mu \mathrm{g} / \mathrm{mL}$ showing $>80 \%$ cell viability) were selected for the subsequent experiment.

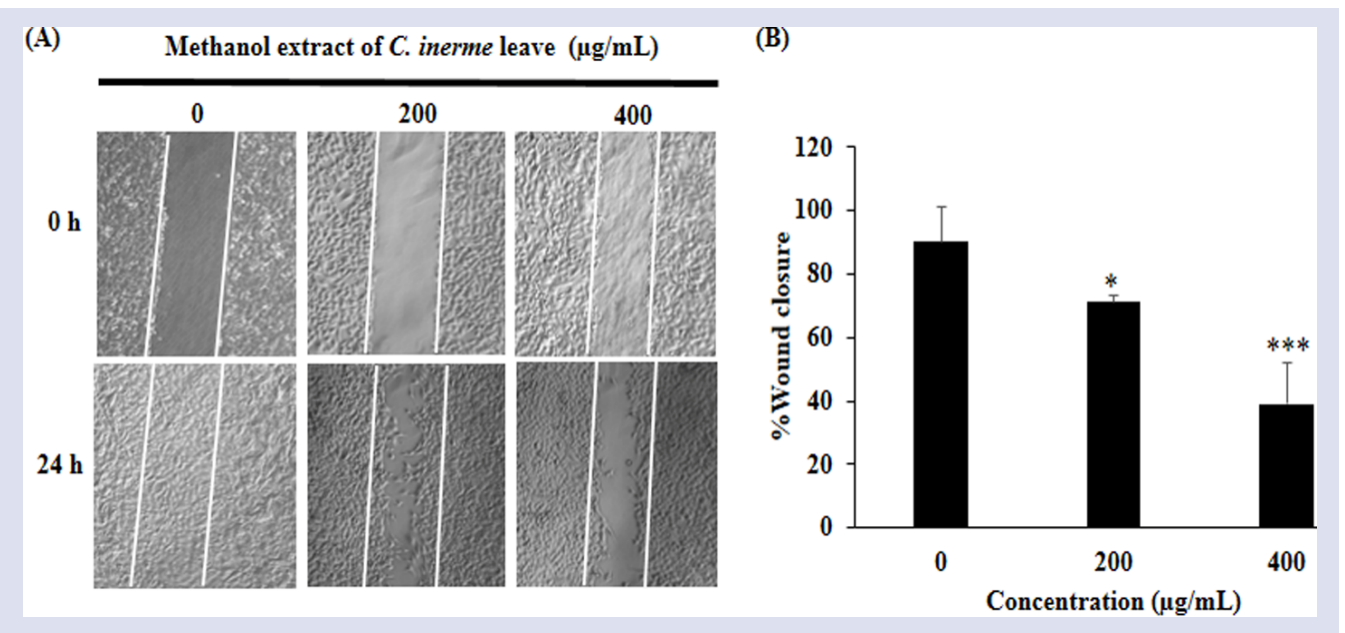

Figure 2: Methanolic leaves extract of $C$. inerme inhibited the $A 549$ cell migration as determined by wound healing assay. The cells were treated with 200 and $400 \mu \mathrm{g} / \mathrm{mL}$ of $C$. inerme leaves extract for 24 hours. (A) Cell monolayers were scratched with a micropipette tip to create the wound area and treated with or without the noncytotoxic concentration of $C$. inerme leaves extract. The cells migrate to the wound area were photographed (40x magnification). (B) Wound closure was analyzed by measuring the area between the edges (white lines indicated the wound edge). Data are presented as mean \pm SD of three independent experiments. ${ }^{*} p<0.05$ and ${ }^{* * *} p<0.001$ compared with the untreated control.

leaves extract of $C$. inerme at 200 and $400 \mu \mathrm{g} / \mathrm{mL}$ inhibited $71.1 \pm 1.91 \%$ and $39.2 \pm 12.67 \%$ of cell migration, respectively. Furthermore, the extract also significantly suppressed cell migration as detected with the transwell chamber as shown in Figure $3 \mathrm{~A}$ and $3 \mathrm{~B}\left({ }^{* *} \mathrm{p}<0.01\right)$. These results indicated that methanolic leaves extract of $C$. inerme significantly inhibited cell migration in A549 cells.

\section{The effect of methanolic leaves extract on $C$. inerme on A549 cell invasion}

Matrigel-coated Boyden chamber assay was performed to investigate the anti-invasion of A549 by methanolic leaves extract on C. inerme. The invaded cells were stained by crystal violet and the percentage of invaded cells was analyzed by NIH ImageJ. The result demonstrated that methanolic leaves extract of $C$. inerme significantly suppressed A549 cell invasion compared with the untreated control $\left({ }^{* *} \mathrm{p}<0.01\right)$ as shown in Figure 4A and 4B. The percentage of invaded cells was $26.20 \pm 4.40 \%$ when treated with the extract at the concentration of $400 \mu \mathrm{g} / \mathrm{mL}$. This result indicated that methanolic leaves extract of $C$. inerme significantly inhibited cell invasion in A549 cells.

\section{Effect of methanolic leaves extract on $C$. inerme on cell adhesion}

Effect of methanolic leaves extract on $C$. inerme on cell adhesion was performed by MTT assay. The result demonstrated that methanolic leaves extract of $C$. inerme could inhibit cell adhesion ability of A549 to Matrigel-coated wells at $29.25 .0 \pm 4.17 \%$ after treatment with 400 $\mu \mathrm{g} / \mathrm{mL}$ of the extract as shown in Figure 5 . This result indicated that the methanolic extract of $C$. inerme leaves significantly inhibited the adhesion ability of lung cancer cells

\section{DISCUSSION}

Metastasis is the major problem for cancer treatment and is responsible for more than $90 \%$ of all cancer-related deaths. Cancer metastasis consists of multi-step and multifunctional biological events which include cell detachment, migration, invasion and adhesion. ${ }^{30}$ At the earliest stage, cancer cells disseminate from the primary tumor, migrate and invade through the basement membrane, survive in the circulatory system, invade into a secondary site, then adhesion and 
(A)

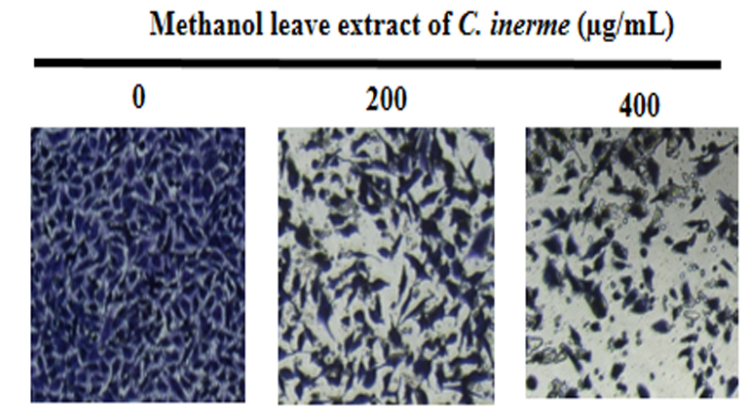

(B)

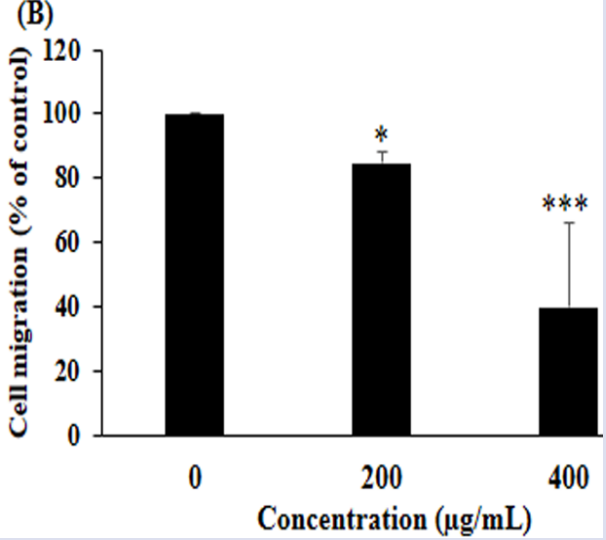

Figure 3: Methanolic leaves extract of $C$. inerme inhibited the $A 549$ cell migration as determined by the transwell chamber assay. The cells were treated with 200 and $400 \mu \mathrm{g} / \mathrm{mL}$ of C. inerme leaves extract for 24 hours. (A) Methanolic leave extract of $C$. inerme also significantly suppressed cell migration as detected with the transwell chamber. The migratory cells were stained with crystal violet and photographed (40x magnification). (B) Quantitative analysis of the migratory cell was calculated by NIH ImageJ. Data are presented as mean \pm SD of three independent experiments. ${ }^{*} p<0.05$ and ${ }^{* * *} p<0.001$ compared with the untreated control.

(A)

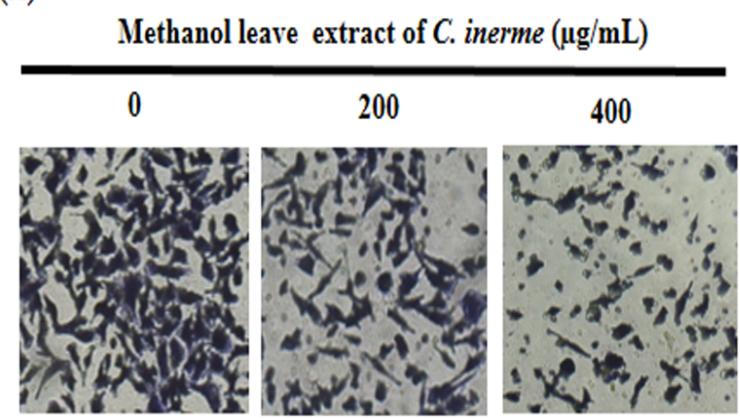

(B)

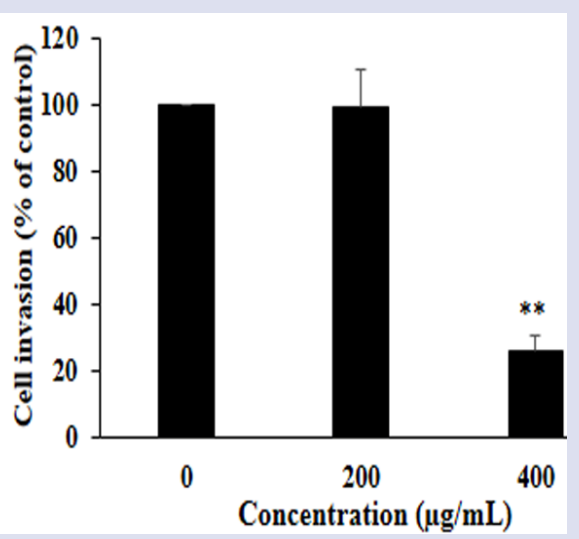

Figure 4: Methanolic leaves extract of $C$. inerme inhibited A549 cell invasion as tested by Matrigel-coated Boyden chamber assay. The cells were treated with 200 and $400 \mu \mathrm{g} / \mathrm{mL}$ C. inerme leaves extract for 24 hours. (A) The invaded cells were stained with crystal violet and (B) the percentage of invaded cells showed significantly decreased after treating with methanol leaves extract of $C$. inerme. Data are presented as mean \pm SD of three independent experiments. ${ }^{* *} p<0.01$ compared with the untreated control group.

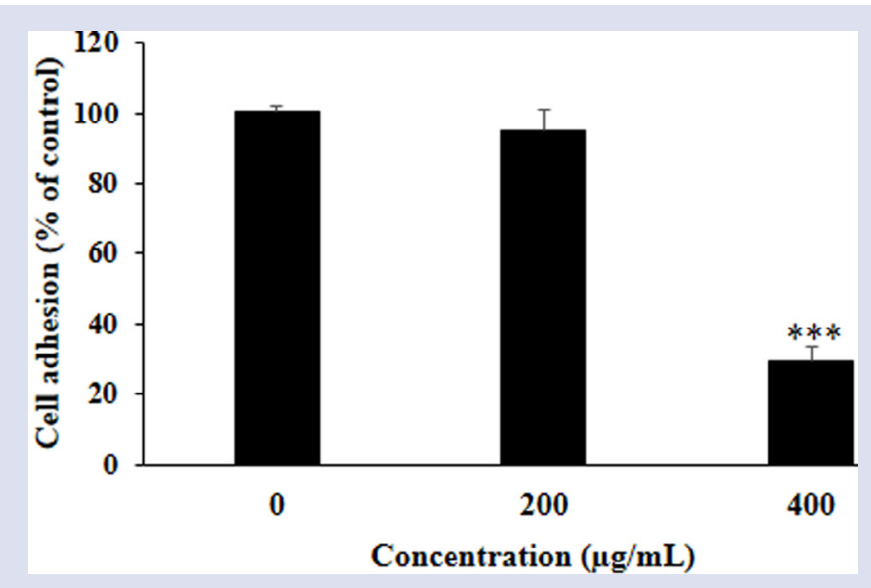

Figure 5: Effect of methanolic leaves extract of $C$. inerme on cell adhesion at 24 hours. The adhesion ability of A549 cells to Matrigelcoated wells was markedly inhibited by methanolic leaves extract of $C$. inerme at a concentration of $400 \mu \mathrm{g} / \mathrm{mL}$ as compared with the untreated control group. Data are presented as mean $\pm \mathrm{SD}$ of three independent experiments. ${ }^{* * *} p<0.001$ compared with the control group. 
start to proliferate. ${ }^{31,32}$ Disruption of any metastatic steps is a target for preventing the development of cancer metastases. Herein, we first demonstrated that the methanolic leaves extract on $C$. inerme inhibited lung cancer cell metastasis by suppressing cell growth, migration, and invasion and adhesion abilities of A549 cells. Before determination of cell migration, the cytotoxicity test was performed to determine a range of crude extract concentrations that provide more than $80 \%$ cell viability. We found that $6.25-200 \mu \mathrm{g} / \mathrm{mL}$ methanolic leaves extract of C. inerme showed no significant effect on cell viability but the high concentration, the extract significantly inhibited cell growth of A549 cells. The $\mathrm{IC}_{20}$ and $\mathrm{IC}_{50}$ were greater than $400 \mu \mathrm{g} / \mathrm{mL}$. This value was higher than the previous studies that showed ethanol leaves extract and hydroalcoholic aerial parts $C$. inerme exhibited anti-proliferation and anti-cancer activities on lung cancer cell line with $\mathrm{IC}_{50}$ values at $15.6 \mu \mathrm{g} /$ $\mathrm{mL}$ and $259.5 \mu \mathrm{g} / \mathrm{mL}$, respectively. ${ }^{25,26}$ To determine the anti-metastatic effects of the extract, the non-toxic concentrations at 200 and $400 \mu \mathrm{g} /$ $\mathrm{mL}$ and allowing over $80 \%$ cell survival were selected. Cell migration and invasion are important steps for the metastasis of cancer cells. The ability of cancer cells to migrate and invade other tissues finally lead to metastasis. In this study, we demonstrated methanolic leaves extract of C. inerme significantly suppressed cell migration and invasion of A549 cells in a dose-dependent manner when compared with the untreated cells $\left({ }^{* *} p<0.001\right)$. Moreover, we found that the methanolic leaves extract of $C$. inerme could inhibit cell adhesion ability of A549 after treatment with $400 \mu \mathrm{g} / \mathrm{mL}$ of the extract as shown in Figure 5. These results indicated that the methanolic left extract of $C$. inerme inhibits cell metastasis of the A549 human lung without apparent cytotoxicity. Several phytochemical constituents have been isolated from $C$. inerme leaves such as alkaloids, flavonoids, terpenes, diterpenes, triterpene which possess many mechanisms of actions such as anti-cancer, anti-proliferation, anti-metastasis, anti-angiogenesis, anti-oxidation activities, cell cycle arrest and induction of apoptosis. ${ }^{33}$ Shen and colleagues demonstrated that acacetin, a flavonoid, inhibits the invasion and migration of human prostate cancer DU145 cells via inactivation of the p38 MAPK signaling pathway. ${ }^{34}$ Previous reports demonstrated that fatty acids extracted from C. volubile leaves could suppress tumor metastasis and invasion in human neuronal glioblastoma cells. ${ }^{35}$ and breast cancer cells. ${ }^{36}$ Although the mechanism underlying antimigration, anti-invasion and anti-adhesion effects are still unclear, the result demonstrated that $C$. inerme methanolic leaves extract could suppress cancer metastasis of lung cancer cell lines. Further study needs to focus on the mechanism involving anti-metastasis and the major active components both in vitro and in vivo for developing a novel chemotherapeutic agent in the future

\section{CONCLUSION}

In the present study, we first demonstrated that methanolic leaves extract of $C$. inerme inhibited cell migration, invasion and adhesion of A549 cells (Figure 6). These findings indicated that methanol leave extracts of $C$. inerme may be used as an anti-metastatic agent for lung cancer. However, further biochemical researches are needed to isolate and identify the active compounds responsible for this pharmacological activity.

\section{ACKNOWLEDGEMENTS}

We gratefully thank to Institute of Research and Innovation, Walailak University "Research Grant No. WU60311" for financial support in

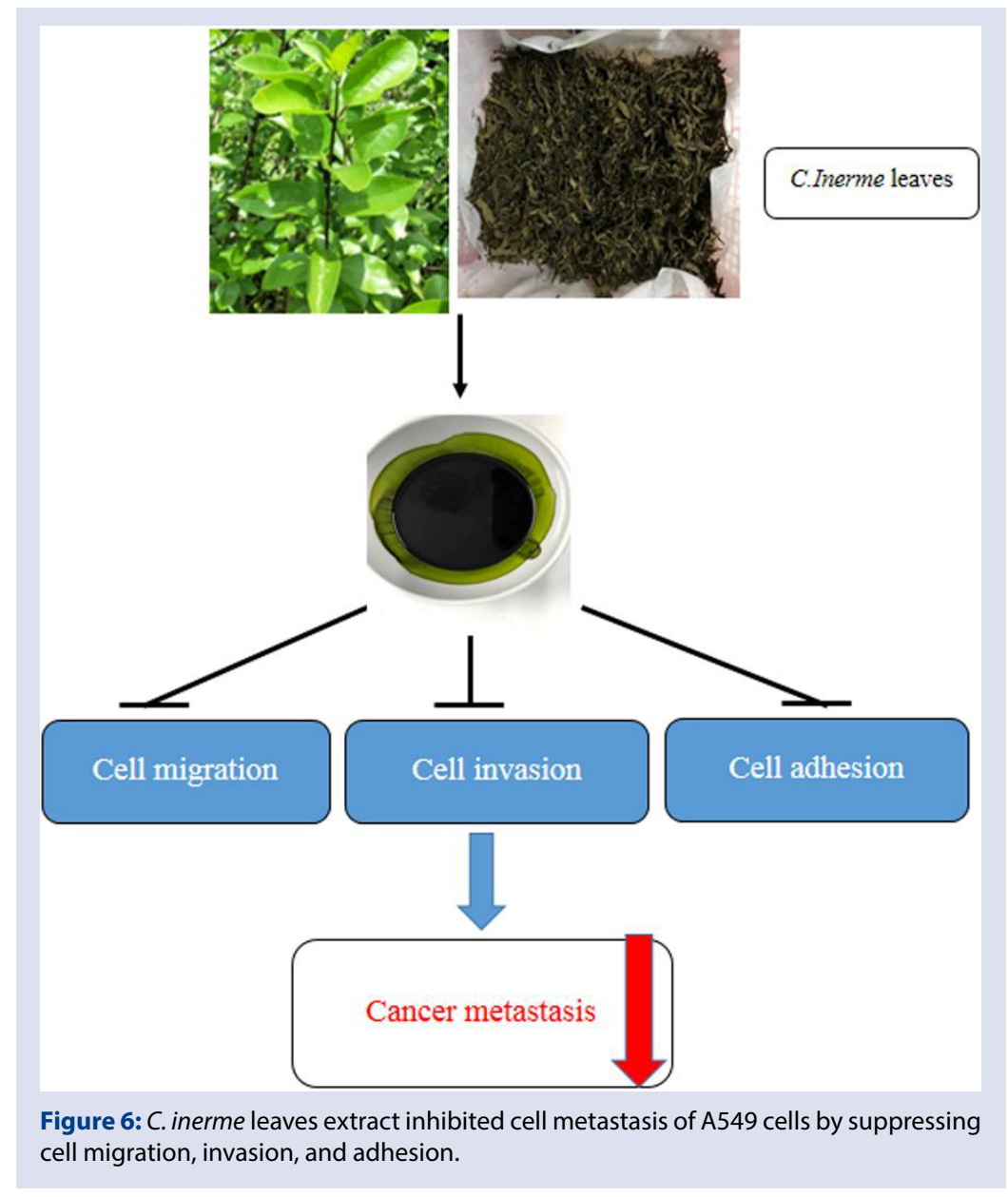


the study. We wish to thank Prof. Vu Thi Thom for assisting in the manuscript preparation.

\section{CONFLICTS OF INTEREST}

The authors declare that they have no competing interests.

\section{ABBREVIATIONS}

MTT: 3-(4,5-dimethyl 2-thiazolyl)-2,5-diphenyltetrazolium bromide; IC $_{20}$ : The $20 \%$ inhibitory concentration; IC IC $_{50} 50 \%$ inhibitory concentration; $\mathrm{CO}_{2}$ : Carbon dioxide; FBS: Fetal bovine serum.

\section{REFERFNCES}

1. Dela Cruz CS, Tanoue LT, Matthay RA. Lung Cancer: Epidemiology, Etiology, and Prevention. Clin Chest Med. 2011;32(4):605-44.

2. Zappa C, Mousa SA. Non-small cell lung cancer: current treatment and future advances. Transl Lung Cancer Res. 2016;5(3):288-300.

3. Gupta GP, Massagué J. Cancer metastasis: building a framework. Cell. 2006;127(4):679-95.

4. Hirsh V, Major PP, Lipton A, Cook RJ, Langer CJ, Smith MR, et el. Zoledronic acid and survival in patients with metastatic bone disease from lung cancer and elevated markers of osteoclast activity. J Thorac Oncol. 2008;3(3):228-36.

5. Mitra SK, Schlaepfer DD. Integrin-regulated FAK-Src signaling in normal and cancer cells. Curr Opin Cell Biol. 2006;18(5):516-23.

6. Wang JH, Luan F, He XD, Wang Y, Li MX. Traditional uses and pharmacological properties of Clerodendrum phytochemicals. J Tradit Complement Med. 2018;8(1):24-38.

7. Rabiul H, Subhasish M, Sinha S, Roy MG, Sinha D, Gupta S. Hepatoprotective activity of Clerodendron inerme against paracetamol induced hepatic injury in rats for pharmaceutical product. IJDDR. 2011;3:118-26.

8. Muthu C, Ayyanar M, Raja N, Ignacimuthu S. Medicinal plants used by traditional healers in Kancheepuram District of Tamil Nadu. J Ethnobiol Ethnomed. 2006;2:43.

9. Kanchanapoom T1, Kasai R, Chumsri P, HiragaY, Yamasaki K. Megastigmane and iridoid glucosides from Clerodendrum inerme. Phytochemistry. 2001;58(2):3336.

10. Al-Snafi AE. Chemical constituents and pharmacological effects of Clerodendrum inerme- A Review. SMU Medical Journal. 2016;3(1):129-52.

11. Kalyani SS, Holihosur RSN. Toxic effect of crude aqueous leaf extracts of Clerodendron inerme, on the total haemocyte count of sixth instar larva of Helicoverpa armigera (H). IJIRST. 2015;1:221-24.

12. Gopal N, Sengottuvelu S. Hepatoprotective activity of Clerodendrum inerme against CCl4 induced hepatic injury in rats. Fitoterapia. 2008;79(1):24-6.

13. Yankanchi SR, Koli SA. Anti-inflammatory and analgesic activity of mature leaves methanol extract of Clerodendrum inerme L. (Gaertn). J Pharm Sci Res. 2010;2:782-5.

14. Sabrin F, Hasan MN, Rahman MM, Islam KD. Investigation on antimicrobial activities of the two selected shrubs from the Sundarbans (Clerodendrum inerme and Caesalpinia crista). JDS. 2011;5(2):62-9.

15. Wutithamawech W, Tantirungkij M, Liangsakul P. Antibacterial potential of some Thai medicinal plants. Int. J Pharma Bio Sci. 2014;5(1):412-21.

16. Chahal JK, Sarin R, Malwal M. Efficacy of Clerodendrum inerme (Garden quinine) against some human pathogenic strains. Int $\mathrm{J}$ Pharm Bio Sci. 2010;1:219-23.

17. Khan SA, Rasool N, Riaz M, Nadeem R, Rashid U, Rizwan K, et al. Evaluation of antioxidant and cytotoxicity studies of Clerodendrum inerme. Asian $\mathrm{J}$ Chem. 2013;25(13): 7457-62.
18. Panigrahi BK, Mishra SK, Sahu SK. Antidiabetic effects of Clerodendrum inerme (L) Gaertn. IJPPR Human. 2015;4(2); 248-56

19. Patil PB, Kallapur SV, Kallapur VL, Holihosur SN. Clerodendron inerme Gaertn. plant as an effective natural product against dengue and filarial vector mosquitoes. APJTD. 2014;4(1):S453-62.

20. Krishnamoorthy JR, Ranjith MS, Gokulshankar S, Sumithra R, Ranganathan S Mohanty B. Effective management of allergy by a siddha preparation- An in vitro study. EDOJ. 2011;7(1):1.

21. Rajalingam K, Renju GL, Balakrishnan S, Manoharan S. Effect of Clerodendron inerme on erythrocyte membrane integrity during 7,12-dimethylbenz(a) anthracene induced skin carcinogenesis in Swiss albino mice. Asian J Sci Res. 2008;1(3):246-55.

22. Renju GL, Manohanan S, Balakrishan S, Senthil N. Chemopreventive and antilipidperoxidative potential of Clerodendron inerme $(\mathrm{L})$ Gaertn in 7,12-dimethylbenz(a) anthracene induced skin carcinogenesis in Swiss albino mice. Pak J Biol Sci. 2007; 10(9):1465-70.

23. Manoharan S, Kavitha K, Senthil N, Renju GL. Evaluation of anticarcinogenic effects of Clerodendron inerme on 7,12-dimethylbenz(a) anthracene-induced hamster buccal pouch carcinogenesis. Singapore Med J. 2006;47(12):1038-43.

24. Kumar CM, Jayadevappa HP, Vasudev HH. Evaluation of Clerodendrum inerme (L.) Gaertn. on burkitt's lymphoma cancer. IJPER. 201;52(2):241-47.

25. Kalavathi R, Sagayagiri R. Anticance activity of ethanolic leave extract of Clerodendrum inerme against lung adenocarcinoma epithelial cell line. EJMBB. 2016;3:69-72.

26. Chouhan MK, Hurakadle PJ, Hegde HV. Clerodendrum inerme (L.) Gaertn. extract exerts anticancer activity on lung cancer cells. Dhaka Univ J Pharm Sci. 2018;17(2):191-6

27. Shaw LM. Tumor cell invasion assays. Methods Mol Biol. 2005;294:97-105.

28. Liu KC, Huang AC, Wu PP, Lin HY, Chueh FS, Yang JS, et al. Gallic acid suppresses the migration and invasion of $\mathrm{PC}-3$ human prostate cancer cells via inhibition of matrix metalloproteinase-2 and -9 signaling pathways. Oncol Rep. 2011;26(1):177-84.

29. Geng L, Ali SA, Marshall JF, Mackay CL, Hart IR, Delcommence M, et al Fibronectin is chemotactic for CT26 colon carcinoma cells: sub-lines selected for increased chemotaxis to fibronectin display decreased tumorigenicity and lung colonization. Clin Exp Metastas. 1998;16(8):683-91.

30. Guan X. Cancer metastases: challenges and opportunities. Acta Pharm Sin B. 2015;5(5):402-18.

31. Lu CC, Yang JS, Chiang JH, Hour MJ, Amagaya S, Lu KW, et al. Inhibition of invasion and migration by newly synthesized quinazolinone MJ-29 in human oral cancer CAL 27cells through suppression of MMP-2/9 expression and combined down-regulation of MAPK and AKT signaling. Anticancer Res. 2012;32(7):2895-903.

32. Bozzuto G, Ruggieri P, Molinari A. Molecular aspects of tumor cell migration and invasion. Ann Ist Super Sanita. 2010;46(1):66-80

33. Krishnadhas L, Santhi R, Annapurani S. Isolation and identification of flavonoid fractions from the leaves of Volkameria inermis and its in vitro cytotoxic study. IJPCR. 2016;8(12):1648-53.

34. Shen KH, Hung SH, Yin LT, Huang CS, Chao CH, Liu CL, et al. Acacetin, a flavonoid, inhibits the invasion and migration of human prostate cancer DU145 cells via inactivation of the p38 MAPK signaling pathway. Mol Cell Biochem. 2010;333(1-2):279-91.

35. Erukainure OL, Ashraf N, Naqvi AS, Zaruwa MZ, Muhammad A, Odusote AD, et al. Fatty acids rich extract from Clerodendrum volubile suppresses cell migration; abates oxidative stress; and regulates cell cycle progression in glioblastoma multiforme (U87 MG) cells. Front Pharmacol. 2018;9:251.

36. Erukainure OL, Zaruwa MZ, Choudhary MI, Naqvi SA, Ashraf N, Hafizur RM, et al. Dietary fatty acids from leaves of Clerodendrum volubile induce cell cycle arrest, downregulate matrix metalloproteinase-9 expression, and modulate redox status in human breast cancer. Nutr Cancer. 2016;68(4):634-45. 


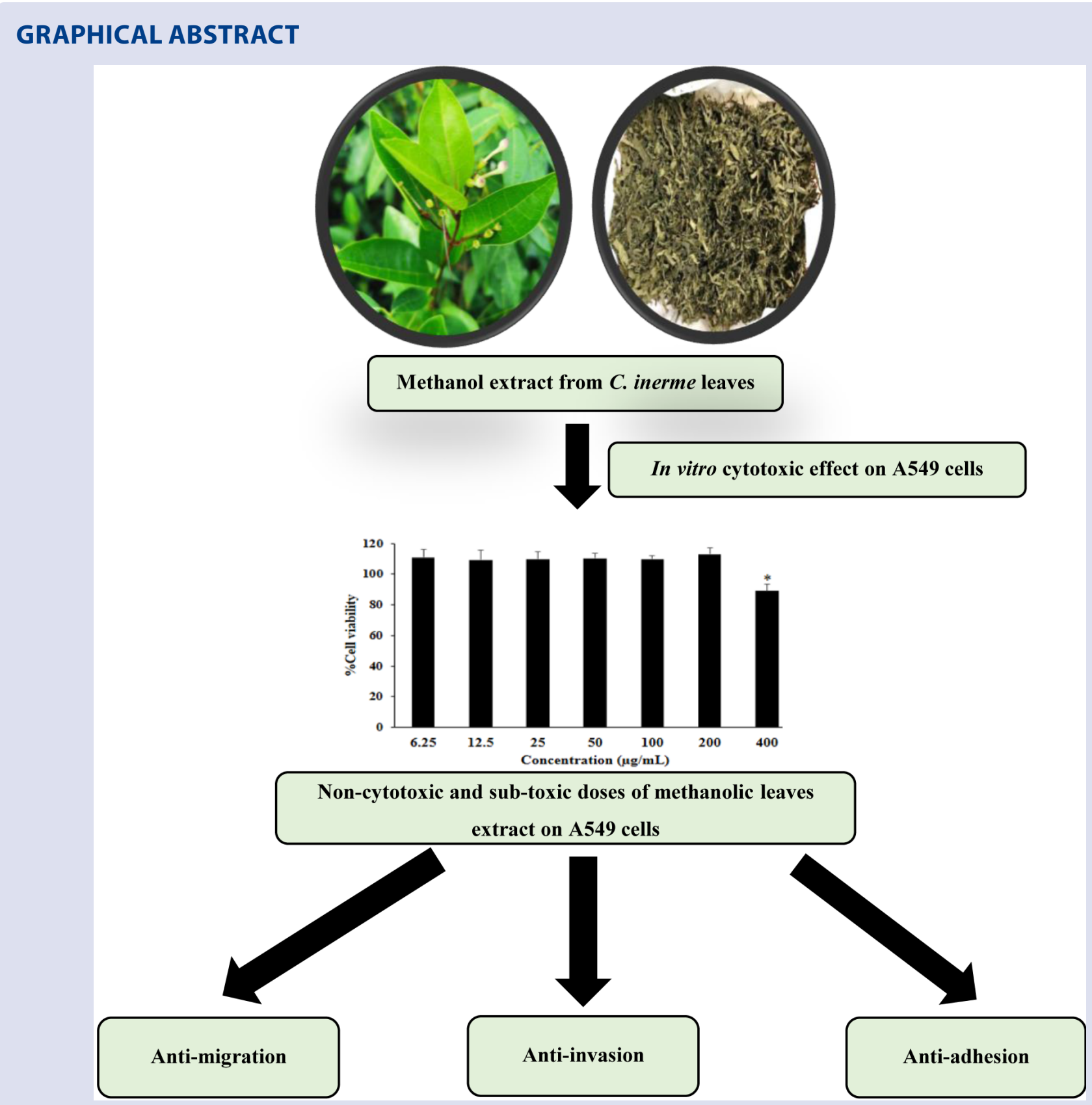

\section{ABOUT AUTHORS}

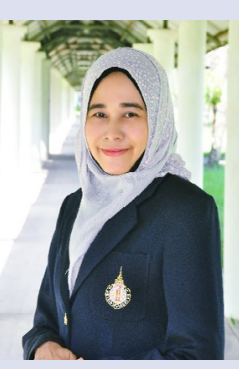

Dr. Malatee Tayeh: Lecturer in Medical Technology at School of Allied Health Sciences, Walailak University, Thailand. Her research interests include cancer biology, cancer metastasis, and hemostasis. 


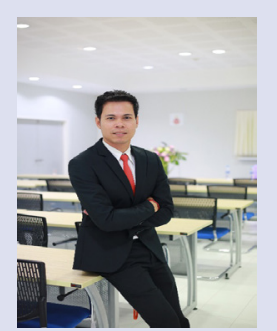

Dr. Poonsit Hiransai: Assistant Professor in Medical Technology at School of Allied Health Sciences, Walailak University, Thailand, and recognized the Senior Fellowship by Advanced Higher Education. His current research interests focus on issues in immuno-modulation, cell signaling transduction, and natural products.

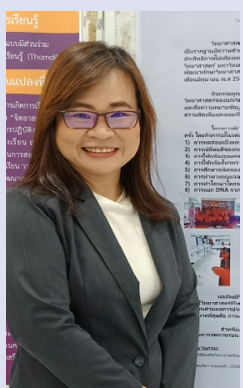

Dr. Hathaichanok Kommen: Assistant Professor in Chemistry at School of Sciences, Walailak University, Thailand. Her research interest is in Natural Products. Study of active compounds from plants. She is also interested in chemistry education which is the study of the teaching and learning of chemistry in universities. The topics would include understanding how students learn chemistry, how best to teach chemistry, and how to improve learning outcomes by changing teaching methods.

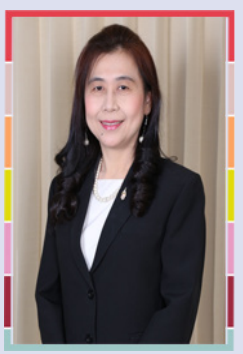

Dr. Ramida Watanapokasin: Associate Professor at Department of Biochemistry, Faculty of Medicine, Srinkharinwirot University, Thailand.

Cite this article: Tayeh M, Hiransai P, Kommen H, Watanapokasin R. Anti-migration and Anti-invasion Abilities of Methanolic Leaves Extract of Clerodendrum Inerme on Lung Cancer Cells. Pharmacogn J. 2020;12(5):1024-31. 